УДК 783.27:781.6.071.1 (470)] (045)

DOI https://doi.org/10.24919/2308-4863/34-2-6

Юлія ІВАНОВА,

orcid.org/0000-0001-5529-5713

кандидат мистецтвознавства,

дочент кафедри академічного співу та хорового диригування

Харківської державної академії культури

(Харків, Україна) ivochkajulia843@gmail.com

\title{
ІНТЕРПРЕТАЦІЯ ПСАЛМА 54 «ВНУШИ БОЖЕ МОЛИТВУ МОЮ» У ТВОРЧОСТІ О. АРХАНГЕЛЬСЬКОГО, О. ГРЕЧАНІНОВА ТА В. ФАЙНЕРА
}

Стаття розкриває особливості композиторських інтерпретачій 54-го псалма в композиціях із церковнослов'янським текстом. Інтерес людства до псалмів як до нескінченного джерела натхнення викликав значну кількість творів у музиці. Найвищі художні досягнення композиторів пов'язані з утіленням псалмів у жанрі духовного концерту.

Мета статті - проаналізувати особливості використання тексту та музично-виразних засобів в обраних творах. Визначено стильову індивідуальність авторів, яка трунтується на глибокому переосмисленні сакрального тексту псалма. Виявлено, щзо композитори, коли звертаються до визначених строф 54-го псалма, розкривають різні грані єдиного образу. Твору О. Архангельського притаманна тема молитви та каяття, образи віри та надії оспівує О. Гречанінов, В. Файнер тяжіє до медитативного сприйняття псалма, спонукає слухачів до філософських роздумів. Доведено, щзо повторення слів, окремих фраз тексту з метою підкреслення сутності псалма надає можливість композиторам розширити коло музичних засобів та збагатити образно-смисловий зміст твору.

Здійснено аналіз засобів музичної виразності творів, виявлено особливості молитовних інтонацій у зв 'язку зі змістовно-образним наповненням. Уперше проаналізовано композиторську інтерпретацію псалма у творчості B. Файнера, у творі поєднано західноєвропейську техніку письма із традиціями вітчизняного духовного співу.

Розглянуто відповідність музичної мови творів церковним канонам. Музична мова творів О. Архангельського та В. Файнера за яскравої художності не суперечить иерковним канонам. Концерт О. Гречанінова, сповнений екзальтованого драматизму та емоиійності, тяжіє до світського жанру. Окреслено деякі особливості виконавської інтерпретачії творів. Виявлено, щзо особливу роль у створенні художнього образу творів відіграють тональності, які несуть у собі певне образно-смислове навантаження. Визначено, незважаючи на самобутність кожної композиторської інтерпретації 54-го псалма, можна говорити про єдину, виразно окреслену, сумарну інтонаційно-художню ідею творів, яка виникає з його канонічного змісту.

Ключові слова: композиторська інтерпретація, канонічний текст, музично-поетичний синтез, художній образ, драматургія, інтонація.

Yuliia IVANOVA, orcid.org/0000-0001-5529-5713 Candidate of Art History, Associate Professor at the Department of Choral Conducting and Academic Singing Kharkiv State Academy of Culture (Kharkiv, Ukraine) ivochkajulia843@gmail.com

\section{INTERPRETATION OF PSALM 54 "COMPEL GOD TO MY PRAER" IN THE WORKS OF A. ARKHANGELSKY, A. GRECHANINOV, V. FINER}

The article shows the features of the composers' interpretations of the Psalm 54. All of them are based on the Church Slavic language. The human interest to these texts is evident because of the endless inspiration. This fact brought us a great number of art pieces. The most significant ones are written in the spiritual concert form.

The aim of the article is to analyze the features of the text and musical tools used in the chosen art piece. We identified the individual style of the authors which is based on the deep reconsciouness of the sacral psalm text. The difference between using various strophes of the Psalm by the composers shows their individual perception. This technique gives diverse nuances to the artistic image. According to this the themes of praying and repentance are inherent in the piece of A. Arkhangelsky. At the same moment A. Grechaninov praises faith and hope. In the same time V. Fainer is much closer to the meditative comprehension of the Psalm, what encourages the philosophical reflection.

It was proved that the repetition of the words and phrases have the aim of highlighting the essence of the piece. This gives the composer an opportunity to expand the number of musical tools and enrich a semantic and image content. During the analyzes of the musical tools we found out some features of the praying intonations corresponding to the 
content. The composer's interpretation of V. Fainer was analyzed the first time. We found out that he combined WestEuropean writing tradition with a native spiritual singing.

We also reviewed a compliance of the musical language to church rules. The musical language of the compositions by A. Arkhangelsky and V. Fainer do not contravene the church traditions though the bright artistry. The concert written by A. Grechaninov is full of exalted drama and emotions what makes it closer to the secular genre. We also found out some specialities of the performing interpretation.

It was found out that music tones have definite meaning and a symbolic value, that is why they have a special part in the process of forming an artistic image. Despite of the originality of the each interpretation of the Psalm 54 we can still discuss general art and intonation idea of the art works which is justified with the canonic meaning.

Key words: composer's interpretation, canonical text, synthesis of music and poetry, art image, dramaturgy, intonation.

Постановка проблеми. Унікальний інтерес людства до псалмів як до нескінченного джерела натхнення пояснюється їхньюю неймовірною силою передавати людські думки та почуття. В історії світової музики псалмам належить особливе місце серед канонічних текстів. Творчість композиторів спрямована на втілення сакральних смислів, що закладені в текстах псалмів: проблеми пошуку сенсу життя, призначення людини, біблійного екуменізму.

Творчий потенціал псалмів викликав значну кількість творів у музиці, що представляють тлумачення псалмів як динамічного і поки ще не сформованого остаточно жанру. Поряд із літургічним статусом псалом набуває статусу світського жанру концертного плану, що проявляється в незалежності музичної мови від церковних канонів.

Найвищі художні досягнення композиторів пов'язані з утіленням псалмів у жанрі духовного концерту, бо саме концерт надає широкі можливості для розкриття творчого потенціалу композиторів.

Актуальність обраної теми зумовлена широким колом функціонування тематики псалмів не тільки в композиторському просторі сучасності, а й попередніх століть. Тексти псалмів використовували у своїх творах М. Регер, А. Шенберг, А. Онеггер, Л. Бернстайн, К. Пендерецький, Д. Раттер, І. Стравинський, М. Скорик, С. Станкович, Г. Гаврилець, В. Польова, Л. Дичко, О. Козаренко, В. Камінський, М. Шух, О. Щетинський. В. Степурко, I. Щербаков, В. Сильвестров; а також представники творчої молоді України О. Юнек, В. Файнер та інші.

Аналіз досліджень. На сучасному етапі в умовах розквіту величезного прошарку сучасної духовної музики питання інтерпретації псалмів у творчості композиторів усе більше приваблюють музикознавців. Зазначена проблематика висвітлюється багатьма дослідниками України та зарубіжжя: Н. Герасимовою-Персидською, О. Шуміліною, Т. Гусарчук, С. Літвіновою, Н. Лозівською, Л. Герасименко, Л. Півторацькою, Н. Гуляницькою, Т. Сухомліновою й іншими.
Мета статті - розглянути особливості використання тексту та музично-виразних засобів у композиторських інтерпретаціях 54-го псалма.

Завдання статті передбачають: виявлення особливостей використання строф псалма композиторамиузв' язкузособистимсприйняттямйогозмісту; проведення аналізу музично-драматургічних, формотворчих та стилістичних особливостей хорових творів на текст 54-го псалма; окреслення деяких складників виконавської інтерпретації творів.

Методологія дослідження включає компаративний метод, що застосовується для порівняння особливостей використання тексту псалма; історичний - для аналізу хорів різних епох та стилів; аналітичний - для аналізу музично-драматургічних, формотворчих та стилістичних особливостей даних творів.

Виклад основного матеріалу. Авторство 54-го псалма приписують царю Давиду. Псалмоспівець описує свої страждання від зрадників, його сина Авессалома та друга Ахіофела. Давид перебуває у відчаї, але він знає, що Господь почує його і захистить від ворогів у часи тяжких душевних страждань.

Ознайомлення зі змістом псалма надає можливість зробити висновок, що композитори невипадково звернулися до цього тексту, у ньому втілено глибокі переживання людини, яка потерпає від страху та невіри й уповає тільки на Бога. Кожний композитор у своїх творах використовує окремі строфи із псалма, тому твори набувають різноманітних відтінків образного змісту псалма. Вербальною основою творів, обраних для розгляду, $\epsilon$ канонічний церковнослов' янський текст.

Порівняємо особливості використання псалма в концертах «Внуши Боже» О. Архангельського, О. Гречанінова та В. Файнера.

Одним із перших композиторів, хто звернувся до тексту 54-го псалма «Внуши Боже молитву мою» (Концерт № 13) був О. Архангельський. Твір написано в 1895 р. У концерті панує глибока скорботність душі, яка страждає, шукає спасіння в милосерді Божому. Тому автор використовує 1, 2, 4, 5 та 16 строфи псалма, у яких відтворено благання людини і віру в те, що Господь почує іiі. 
Жанр концерту був заперечений Синодом більше 50-ти років, і саме О. Архангельський серед перших відроджував цей змістовний жанр. Він створив свій варіант духовного концерту, у якому яскраво виявилася творча індивідуальність композитора.

Починається концерт чоловічою групою хору. Тенори та баси почергово проводять тему, інтонаційність якої споріднена з романсами._Завдяки романсовим інтонаціям підсилюється емоційно виразне звертання до Бога. Перша строфа псалма повторюється декілька разів, водночас музичний матеріал варіюється, зберігає звертальні інтонації. Перша половина другої строфи «Вонми и услыши мя» сповнена відчайдушного благання, що відтворюють на початку тембри жіночого хору. Крім варіаційності тематизму, у повторах наявне тональне зіставлення g-moll та c-moll, що надає проханням різних емоційних відтінків. Друга половини строфи «Воскорбех печалию моею» вирішена за тими ж принципами, що і попередні: 3 використанням перекличок чоловічих та жіночих голосів із подальшим гальмуванням темпу, довгих акордів у кадансі на тексті «и смятохся». Четверта строфа псалма «Серце мое смятейся во мне» відокремлюється новим тематизмом вузького діапазону і повторюється декілька разів, розвивається за допомогою секвенції, яка приводить до першої кульмінації концерту «И боязнь смерти нападе на мя». Почуття страху, тріпотіння, серцевого збентеження відтворює наступний розділ концерту (строфа 5 «Страх и трепет прииде на мя»). Душевний стан страху виражений динамічним зростанням та септакордовим співзвуччям на тлі органного баса. Почуття страху додають i секундові інтонації, що постійно повторюються і створюють сум'яття та занепокоєння. Слова «и покры мя тьма» зображені поступовим низхідним рухом баса, відтворюють насування мороку. Останній розділ концерту (16 строфа) - це хорал, образ смирення, сповнений надії, віри, світла, «Аз к Богу воззвах» звучить у тональності Es-dur. Мажорний хорал виступає як символ просвітлення, знаходження сили духу та стійкості віри.

Форму концерту - строфічну - вибудовує сам текст псалма. Кожна строфа передає різні відтінки душевних переживань людини, де поступово накопичується емоційна напруга.

Композитор майстерно користується інтонацією як найважливішим смисловим елементом музично-поетичного синтезу. У результаті аналізу хорового тла ми можемо зробити висновок, що на інтонаційному рівні автор створив цілісну наскрізну форму, де злилися воєдино музична та мовна інтонації. Концерту властиві широкі інтонації - стрибки на сексту, висхідний рух тризвуками та їх оберненнями, що притаманні романсовій ліриці. Особливу роль відіграють висхідні та низхідні інтонації, побудовані в об'ємі терції. Вони існують у багатоваріантності, що збагачує образ концерту різними відтінками єдиного образу. Отже, можна говорити про монотематизм концерту. Багатоваріантність терцевих інтонацій споріднює тематизм твору 3 народною піснею. Народнопісенні інтонації-теми автор майстерно розвиває за допомогою секвенцій. Типовими для західноєвропейської музики є каданси, що завершують епізоди форми. Це субдомінантова, домінантова та тонічна функції із затриманням.

Розділи форми твору підкреслені різноманітними типами фактури. Найпоширеніший принцип використання фактури - розшарування музичної тканини на два самостійні пласти, що проводиться чоловічою та жіночою групами хору. Деякі епізодні форми починаються сольним викладенням теми однією партією, тенорами або басами. Мелодія, що не підтримана гармонічними барвами, стає символом одинокої душі, що страждає та шукає заспокоєння в Бога.

Мінорний лад концерту занурює в образ скорботи та суму. У творі спостерігається тональна мінливість (g-moll - c-moll), вона також сприяє виявленню різноманіття емоційних відтінків образного стану (туга, скорботність, зосередженість, тріпотіння, молитва, хвилювання тощо). Виразність мелодії концерту підкреслюється барвистою романтичною гармонією, збагаченою альтерацією, великою кількістю акордів побічних ступенів ладу та модуляціями.

Драматична кульмінація концерту припадає на 5 строфу, вона досягається завдяки подрібненню ритмічної структури музичної тканини, секвенційному розвитку, великій кількості альтерованих напружених акордів та зростанню динаміки. Але, на думку автора, кульмінацією твору можна назвати саме просвітлений хорал. Це приклад так званої тихої кульмінації. Саме в цій 16 строфі в хоралі сконцентрована ідея псалма - звернись до Господа і він почує тебе.

Концерт «Внуши Боже» О. Гречанінова op. 26 (1901р.) має зовсім інший настрій, ніж твір О. Архангельського. У ньому панують не тільки скорботність та каяття, а й висловлюється віра в милість Господню, віддання йому хвали та надія на краще. Автор для посилення величі Бога в концерті використовує строфи із 17-го псалма, що додає образному змісту твору урочистої піднесеності. Твір має тричастинну 
структуру. У першій частині концерту - звертанні до Бога («внуши Боже, услыши мя, вопль мой внидет во уши его») автор використовує 1 та 2 строфи 54-го псалма та 6 строфу 17-го псалма. Друга частина концерту розповідає про зішестя Бога 3 небес («и наклонил он небеса, и возгремел с небес Господь, и Всевышний дал голос свій»). У ній композитор використовує 9.10, 12 та 13 строфи 17-го псалма, і тільки останні фрази (16 та 17 строфи 54-го псалма) частини повертають слухачів у стан каяття та молитви. Останній розділ концерту - це натхненна пісня подяки та хвали Господу, це 46, 1 та 2 строфи 17-го псалма. Автор навмисне на початку ставить 46 строфу псалма «Жив Господь і благословен», чим підкреслює провідну роль Господа в житті людини.

Завдяки синтезу слова і музики зміст тексту набуває емоційно-духовної сили, що має величезний вплив на слухачів. Образний зміст концерту зумовлює домінування величальних, хвалебних піснеспівів із яскравими, світлими мажорними барвами, насичених акордів із деталізованою фактурою, широким діапазоном.

Композитор використовує основну тональність cis-moll, яка вважається однією з найбільш похмурих тональностей. Ї̈ї образно-темброві барви сповнені водночас любові та суму. Для відтворення образу страждання та горя в частині концерту композитор надає численну кількість затримань у гармонічній тканині концерту. Завдяки цьому в голосах виникають інтонації плачу та туги. Композитор декілька разів повторює текст «Воскорбех печалию моею», з'єднує його за допомогою інтонацій плачу в короткі фрази з ефектною, повнозвучною гармонією, що наближає музику концерту до світської. Інтонаційний розвиток призводить до перерваного кадансу (A-dur тризвук), що символізує інтонацію невирішеного питання.

Автор використовує мінливий лад (cis-moll E-dur), який передає зміни настрою людини - від туги до надії. Розвиток музичної тканини приводить до кульмінації і припадає на слова «Призвах Господа и к Богу воззвах», вона звучить у мажорі (E-dur), саме тут починає стверджуватися концепція концерту - від морока до світла.

Друга частина концерту контрастує за темпом, характером, фактурою та тональністю. Образ самого Господа композитор вирішує мажорною тональністю (A-dur). Темброві барви цієї тональності мають великий вплив. Саме ця тональність використовується для виразу сокровенних почуттів. Вона сповнена віри та надії, випромінює любов та непідробну радість, що так співзвучно образному змісту частини. Починається друга частина урочистим маршоподібним хоралом, сповненим призивних квартових інтонацій. Марш безпосередньо переростає в імітаційні повтори тексту «И мрак под ногами Его», розвиток яких приводить кульмінації, яка звучить у тональності Fis-Dur. Ця тональність дуже яскрава та чиста, у ній відчувається подих полегшення, вона сповнена тріумфальними барвами перемоги, які закладені в канонічному тексті. Завдяки повторам слів музичний матеріал поліфонізується, насичується альтерованими гармоніями, накопичує енергетику та виростає в розгорнутий каданс: «И возгреме с небес Господь и Вышний даде глас свой», що повертає в тональну сферу A-dur - fis-moll.

Остання музична фраза кадансу музичного стає началом нового тексту 54-го псалма: «Аз к Богу воззвах $<\ldots>$ »). Таким чином виникає тісне наскрізне з'єднання форми твору. Строфа другої частини концерту «И возвещу и услышит глас мой» повертає слухачів в образний стан першої частини концерту. Тематизм розділу дуже стриманий, він успадковує традиції старовинних розспівів: мелодія не має стрибків, викладена в октавний унісон, витримані окремі партії, велика кількість квінт у гармонії, і на останнє - повільний темп. Розділ закінчується Gis-dur тризвуком, що за енгармонічної заміни стає домінантою тональності Des-dur, у якій звучить третій розділ концерту «Жив Господь <..>». Частина досить ємна, водночас у ній використані всього три строфи 17-го псалма. Розширення форми утворюється завдяки повторенням тексту, що стверджує та зміцнює загальну ідею твору - віру у всемогутню силу Бога. Повторення тексту в музичному матеріалі розсвічуються підголосками, що передаються різним хоровим партіям. Музика частини сповнена урочистої величі. Крізь інтонації урочистого хоралу, що пронизують усю частину концерту, встановлюється зв'язок з усім образним змістом концерту. Деякі розділи частини нагадують звучання панегіричних кантів, що були поширені в Росії в XVII ст.

Грандіозне хорове скандування людського натовпу нагадує розділ «Защитник мой, и рог спасения моего». В октавний унісон викладені чоловічі партії, а під час повторення тексту жіночі голоси втручаються у звучання хору, додають хоралу ще більшої урочистості та піднесеності. Останні повторення тексту зміцнюють основну тональність частини спочатку оспівування тонічного тризвуку в положенні квінтового тону, а потім багатократним повторенням цього акорду в мелодичному положенні тоніки. Різноманітні повторення тексту у творі автор майстерно роз- 
поділяє між голосами, щоб слухачі стежили за змістом. О. Гречанінов дуже дбайливо ставився до змісту церковного тексту, він ніколи не спотворював церковний текст перевантаженням засобами музичної виразності, а тільки оновлював музичну мову твору.

Розгорнута складна тричастинна структура концерту, де кожна частина має декілька розділів, об'єднаних загальним змістом, тяжіє до строфічності завдяки великій кількості різноманітних за характером епізодів. Драматургія концерту не зовсім відповідає церковним канонам і надає твору рис світського характеру.

У музиці концерту «Внуши Боже <..>» О. Гречанінова особисте переростає в загальнолюдське - у фіналі звучить не тільки віра в Бога, а й прагнення людини до добра, світла та щастя.

Своєрідним є бачення образного змісту 54-го псалма в концерті сучасного українського композитора В. Файнера. Він використовує тільки дві строфи 54-го псалма - 2 та 22. Друга частина концерту будується на частині 22 строфи псалма: «Возверзя Господи печаль твою и Той тя препитает». Це не просте повторення слів, а надзвичайно важливий момент відтворення образного бачення Божої сили - наполеглива «пропозиція» звернутися до Бога, він почує тебе і не дасть похитнутися у вірі.

Використання тільки двох строф 54-го псалма у творі В. Файнера успадковує традиції творів вільної поліфонії XVIII ст., де із двох - трьох слів розросталися цілі композиції глибокого філософського змісту.

Концерт має форму прелюдії та фуги, що була поширена в інструментальній музиці епохи бароко. Ось слова самого автора про стилістику його творів: «Идея моего сочинительства остается неизменной - претворение в русской духовной музыке принципов старинной европейской «полифонической архитектуры». Церковное пение, в моем понимании, не должно содержать никаких жанрово-бытовых вкраплений, никаких ассоциаций с народной песней, кантом, романсом, танцем <...>» (Файнер, 2012).

Перший розділ-прелюдія (текст 2 строфи) -має хоральний склад, характер зосередженого скорботного роздуму: «Внуши Боже молитву мою и не презри моления моего». За формою - це період, що складається з 8-ми тактів. Гармонічний склад, різний рух, тихше звучання голосів на РР надають цьому образу особливої зосередженості, а закінчення на домінантовому тризвуку в мелодичному положенні ввідного тону - характер запитання. Мелодія хоралу досить гнучка і виразна, деякі інтонації нагадують тему з наступної частини. Хоральний склад має рівний, розмірений рух, що надає звучанню особливої суворості, зібраності, деякої смиренності.

Другий розділ - це фуга, що не має яскравого контрасту 3 хоралом за характером, темпом та динамікою. Вона контрастує лише за фактурою та ритмом. Тема фуги невелика за об'ємом, але досить виразна, пластична та рельєфна, вона близька до інструментальної, водночас має деякі риси, притаманні українській народній пісні (2 такт теми). Ритм протискладнення подрібнюється і має більш жвавий характер порівняно з темою, він щільно пов'язаний із ритмічними формулами теми.

Елементи теми фуги безпосередньо використовуються і в інтермедіях, ніби чіпляються один за одного. Це динамізує фугу і надає благанням до Бога наполегливості. Збереження єдиного темпу протягом всієї фуги, спорідненість інтонацій, ритмічних малюнків, відсутність пауз та фермат надають твору безперервності руху та завершеності форми.

Фуга має дві частини. Перша частина включає експозиційне проведення лише двох партій, після яких проходить інтермедія. Інтермедія побудована на елементах протискладнення з поступовим нашаруванням вільних імітацій у різних голосах. Розгорнута розробка має класичні ознаки: домінантова тональність, вилучення окремих елементів теми.

Експозиція другої частини має стреттне проведення тем, водночас тема тенорів викладена у збільшенні. Звучання теми у збільшенні надає образу фуги деякої урочистості. На відміну від першої частини, друга має репризу, яка представлена проведенням теми тільки в теноровій партії. Закінчується фуга типовим для епохи бароко однойменним мажорним тризвуком.

Висновки. Центром композиторських інтерпретацій творів «Внуши Боже» $є$ людина з її внутрішнім світом, думками та почуттями. Композитори використовують різні строфи 54-го псалма залежно від світобачення й авторського ставлення до поетичного тексту. О. Архангельському притаманна тема молитви та каяття, для розкриття цього образу він використовує строфи псалма. Образи віри та надії оспівує у творі О. Гречанінов, автор додає до строф із 54-го псалма величальні строфи 17-го псалма. В. Файнер тяжіє до медитативного сприйняття світу, тому автор використовує тільки дві строфи 54-го псалма і спонукає слухачів до філософських роздумів. Незважаючи на індивідуальність кожної композиторської інтерпретації 54-го псалма, 
можна говорити про виразно окреслену, єдину, сумарну інтонаційно-художню ідею творів, яка виникає $з$ його ідейно-художнього змісту.

Повторення слів, окремих фраз надають можливість композиторам проявити особистісне відчуття сутності молитви, завдяки варіантам засобів музичної виразності збагатити текст новими барвами.
Сучасний композиторський арсенал вміщує досвід духовної музики різних конфесій, різноманітний інтонаційно-стильовий словник, що відображає нові тенденції осмислення музичного простору.

Перспективи подальших наукових розвідок даної теми полягають у послідовному аналізі невичерпаного джерела інтерпретацій псалмів у творчості композиторів різних епох та стилів.

\section{СПИСОК ВИКОРИСТАНИХ ДЖЕРЕЛ}

1. Герасимова-Персидська Н. Псалтир у музичній культурі України XVI-XVII ст. Науковий вісник Національної музичної академії України імені П. І. Чайковського. Музика і Біблія : збірник наукових прачь за матеріалами Міжнародної наукової конферениії. 1999. Вип. 4. С. 83-89.

2. Гуляницкая Н. Поэтика музыкальной композиции : Теоретические аспекты русской духовной музыки ХХ в. Москва : Языки славянскойкультуры, 2002. 443 с.

3. Шуміліна О. Про два музичні тлумачення тексту 68-го псалма (Концерт Артемія Веделя № 2 «Спаси мя, Боже» та його партесний прототип). Науковий вісник Національної музичної академії Украӥни імені П. I. Чайковського : збірник наукових статей. Вип. 85 : Духовна культура України : традиції та сучасність. Київ, 2010. С. $210-226$.

4. Лозовская Н. В. Книга Псалтирь и её отражение в творчестве композиторов XX в. : автореф. дис. ... канд. искусствовед. : 17.00.02. Москва, 2015. 26 с.

5. В Файнер. Литургия в хорально-полифоническом стиле. Погружение в классику. URL: http://www.intoclassics. net/news/2012-06-17-28707.

\section{REFERENCES}

1. Herasymova-Persydska N. O. Psaltyr v muzychnii kulturi Ukrainy Kh VI - Kh VII st. [Psalter in the musical culture of Ukraine of the 16-17'th centuries.] Scientific Bulletin of the P. I. Tchaikovsky National Academy of Music of Ukraine. Music and the Bible: Collection of Sciences. Proceedings of the International Scientific Conference. 1999. Vol. 4. pp. 83-89. [in Ukrainian]

2. Gulyanitskaya N. S. Poetika muzykalnoy kompozitsii: Teoreticheskiye aspekty russkoy dukhovnoy muzyki XX vek. [Poetics of musical composition: Theoretical aspects of Russian spiritual music. XX Century] M. Languages of Slavic Culture, 2002. 443 p. [in Russian]

3. Shumilina O. Pro eva muzychni tlumachennia tekstu 68-ho psalma (kontsert Artemiia Vedelia № 2 "Spasy mia, Bozhe" ta yoho partesnyi prototyp). [About two musical interpretations of the text of Psalm 68 (concert of Artemiy Wedel № 2 "Save me, God" and his party prototype)] Scientific Bulletin of NMAU. P. Tchaikovsky: a collection of scientific articles. Vip. 85: Spiritual culture of Ukraine: traditions and modernity. K. 2010. pp. 210-226 [in Ukrainian]

4. Lozovskaya N. V. Kniga Psaltir i eye otrazheniye v tvorchestve kompozitorov XX veka. [The book of Psalter and it's reflection in the works of composers of the XX century] the abstract of dissertation of candidate of art history: 17.00 .02 . M. 2015. 26 p. [in Russian]

5. Fayner V. Pogruzheniye v klassiku. Liturgiya v khoralno-polifonicheskom stile. [Immersion in the classics. Liturgy in the chorale-polyphonic style] URL: http:/www.intoclassics.net/news/2012-06-17-28707 [in Russian]. 